\title{
HIRA Gene
}

National Cancer Institute

\section{Source}

National Cancer Institute. HIRA Gene. NCI Thesaurus. Code C75507.

This gene plays a role in heterochromatin formation. 